\title{
THE ANXIENTY OF SPEAKING ENGLISH ABILITY IN ICT USAGE AS MEDIA TEFL ON NURSING STUDENTS OF STIK BINA HUSADA PALEMBANG
}

\author{
By: \\ Arief Pamuji \\ Midwifery Study Program at STIK Bina Husada Palembang, South Sumatera \\ Arief_black85@ymail.com
}

\begin{abstract}
The objective of this research was to find out the description of the anxiety of speaking English ability in ICT usage as media TEFL on nursing students of STIK Bina Husada Palembang. , The sample of this research was taken by using a totaling sampling technique with 18 nursing students of the 3rd semester. The data was obtained from questionnaires and speaking tests in one day. Then from the data analysis, it's obtained that there was based on a questionnaire from 18 students, the study result showed that 1 student never felt anxiety and 2 felt very often. The use of ICT helps them more confidence that form 1 students become 1 student who was in high and 6 in low anxiety level rather than the use of face to face learning that students had a high level in anxiety. The result of the study also obtained the scoring of students' speaking that all of the students got upper 60 and the highest score from 18 students was 97 . The participation of students in zoom or google meetings can be assumed that ICT usage can help the students more active because they can find many sources to develop their knowledge easily and make them more confident.
\end{abstract}

Key words: anxienty, speaking

\section{INTRODUCTION}

In the modern era, the use of information and technology is important.

Since the computerized system is widely used in many aspects, it helps everything be easier. It is used by the school, business, college, company, and even as a formal and informal institution. In the past, the teacher and students have difficulties when they want to find information as a support of the teaching and learning process. They had to read many books to find it, and sometimes they got nothing as a result of the limitation of books or sources. Nowadays, the teacher and student in the school or college can be helped by many information where the user can access the data, ebook, Wikipedia and others whenever and wherever they want.

The information and technology or ICT stand for Information and 
Communication Technology. According

to Hennessy, Ruthven, and Brindley

(2005), ICT is hardware likes Laptop, computer, application, digital equipment, telecommunication facilities, and information system on the internet. By using the ICT, the teacher and students are not only can get the information from the internet but nut also they can use ICT as 2 ways of communication. One of the advantages of ITC is they can more creative and brave to act than they have to use face to face in learning. It is in line with Padurean and Margan (2009) who stated that ICT has four benefits; namely, Capacity to control presentation, Novelty and creativity, Feedback, and Adaptability. ICT itself gives food impact to the users as the needs and their response in learning, they can act, respond, and use the latest news as the materials.

Besides the advantages, ICT usage has disadvantages such as the limitation of connection of internet and facilities 80 such as smartphone or laptop. Based on Livingstone (2012), the ICT is unsuitable to all students because some students are lack experience and even the teacher also has a lack of experience in using ICT as a learning process. The learning that uses the internet such as zoom, google meet, delink is not guaranteed that the students haven't anxiety such as in speaking.

Anxiety is a common reaction of students in English as a foreign language classes. Horwitz (2001) states that onethird of students studying a foreign language experience at least foreign language anxiety at an average level. The anxiety in students makes them harm themselves, they will have a little improvement in their learning achievement. Afraid to act in the class such as in speaking, will lead the keep silent or be passive students. Luo (2013b) argues that anxiety in learning has a very broad negative effect on foreign language learning, especially EnglishYoung (1991) identifies six sources of language anxiety, 
which may be associated with the foreign language classroom environment: personal and interpersonal anxiety, which can be associated with fear of real or anticipated speaking actions, learners 'beliefs about language learning, teachers' beliefs about language instruction, interactions between instructors and students, class procedures, and language examinations. The anxiety in language especially in speaking could be from many factors for example; lack of vocabulary and grammar, dislike of English, or even they do not know about English et al, and unconfidence.

During the speaking class, students sometimes cannot be a good participant. They have difficulties in showing their performance as a result of their anxiety. Speaking is an ability that conveying messages, or ideas to the listener. In speaking, the speaker can deliver their messages or ideas as verbal and nonverbal. The verbal is the way the speaker produces the sound as they communicate to the listener. While the non-verbal is the speaker use sign language or use their body such as move the hands, nodding the head, etc. According to Nunan (2004), speaking is an oral skill and consists of systematic verbal messages to convey meaning. Tarigan (1990) also adds "Speaking is a way to communicate that affects our daily lives". This is in line with Brown (2008) who defines speaking as a productive skill that can be observed directly and empirically; Besides, Harmer (2001) defines speaking as the ability to speak fluently presupposes and not only knowledge of the features of the language, but also the ability to process information and language.

Speaking is communication between speaker and listener, and communication is not only as face to face but also they can use the internet as a conference and communicate with each other. In teaching and learning, some teacher has familiar with zoom meetings or google meet as the way their media. 
The students can show their speaking performance without fear to the other students or mistake in grammatical while they speak to their teacher or their friends by using English. According to Woodrow (2006), the relationship between second language anxiety, speech, and the main causes of anxiety with 275 advanced English students. The results showed that a significant negative relationship was found between second language speaking anxiety and oral performance. The main cause of anxiety was interacting with native speakers and it was concluded that speaking anxiety had a debilitating effect on speaking English for some students

The researcher concluded that the use of ICT can help the teacher running the teaching and learning process on nursing students of STIK Bina Husada and STIKES Pembina Palembang.

\section{METHODOLOGY}

The researcher used a descriptive study in conducting the present research.
In this study, the researcher would like to find out the anxiety of English speaking in ICT usage as media TEFL and speaking test on nursing students of STIK Bina Husada Palembang.

The researcher used the total sampling technique in this study. The study sample was from the 3rd nursing semester student of STIK Bina Husada were 18 students. Therefore, the sample total was 18 from a total of the population.

To collect the data, the researcher obtained the scoring of speaking anxiety and English speaking in one-day meeting.

\section{RESULT AND DISCUSSION}

From analyzing the data, the study found important things. There were some important findings of this study.

First, from English Speaking Anxiety Frequency, in the questionnaire, students were asked to express their anxiety about speaking English with a 
choice of options; very often, often, rarely, and never. The results of the questionnaire above are described in Table 1.

\section{Tabel 1}

English Speaking Anxiety Frequency

\begin{tabular}{ccc}
\hline Frequency & Number & Percentage \\
\hline Very Often & 2 & $11 \%$ \\
Often & 7 & $39 \%$ \\
Rarely & 8 & $44 \%$ \\
Never & 1 & $6 \%$ \\
\hline
\end{tabular}

Based on Table 1, there was 1 student or $5 \%$ who stated that he/she never felt anxious when speaking English, 19 students (42\%) stated that they rarely, 18 students $(40 \%)$ stated that they often and 6 students (13\%) stated that they experienced anxiety very often when speaking English. The percentage of speaking frequency in English can be seen below.

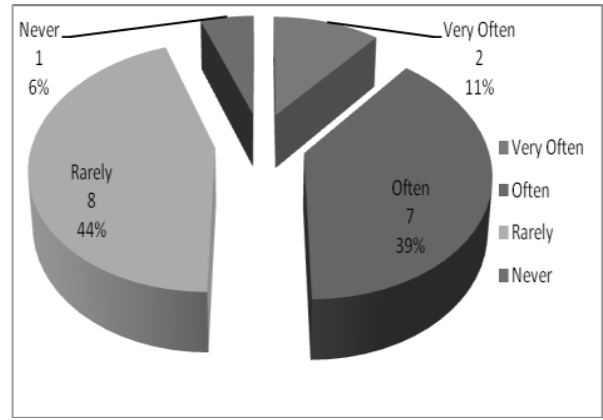

Chart 1. English Speaking Anxienty Frequency
Second, from English speaking anxiety level by face to face learning. The level of anxiety in speaking English is divided into three categories, namely high, middle, and low. The results of the questionnaire are described in Table 2 below.

Table 2

English Speaking Anxiety Level in Face to Face Learning

\begin{tabular}{ccc}
\hline $\begin{array}{c}\text { Anxienty } \\
\text { Level }\end{array}$ & $\begin{array}{c}\text { Frequenc } \\
\mathbf{y}\end{array}$ & Percentage \\
\hline High & 3 & $17 \%$ \\
Middle & 13 & $72 \%$ \\
Low & 2 & $11 \%$ \\
\hline
\end{tabular}

Based on the results of the English speaking anxiety by face to face learning questionnaire, it was found that 3 students $(17 \%)$ were in the high anxiety category, 13 students $(72 \%)$ were in the middle category and 2 student (11\%) were in the low or not anxious category. The percentage of anxiety in speaking English can be in Chart 2. 


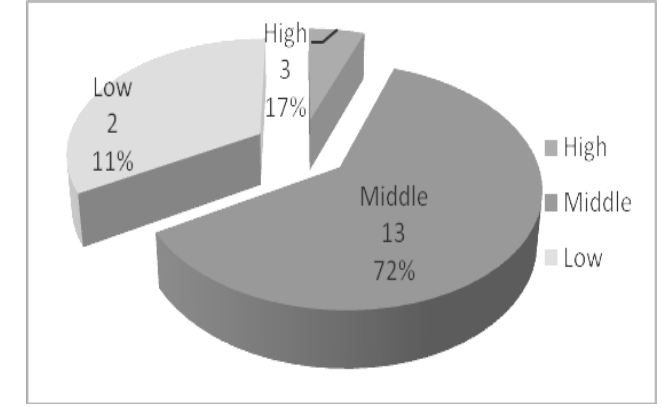

Chart 2. English Speaking Anxiety Level by Face to Face Learning

Third, from English speaking anxiety level by ICT or daring learning.

The results of the questionnaire are described in Table 3 below.

Table 3

English Speaking Anxiety Level by ICT or Daring learning

\begin{tabular}{ccc}
\hline $\begin{array}{c}\text { Anxienty } \\
\text { Level }\end{array}$ & Frequency & Percentage \\
\hline High & 1 & $6 \%$ \\
Middle & 11 & $61 \%$ \\
Low & 6 & $33 \%$ \\
\hline
\end{tabular}

Based on the results of the English speaking anxiety in the face to face learning questionnaire, it was found that 1 student (6\%) was in the high anxiety category, 11 students $(61 \%)$ were in the middle category and 6 student (33\%) were in the low or not anxious category. The percentage of anxiety in speaking
English can be in Chart 3.

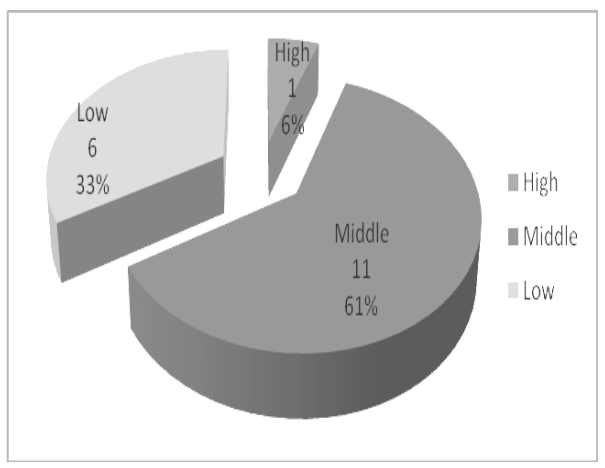

Chart 3. English Speaking Anxiety Level by ICT or Daring Learning

Fourth, from the English speaking score, the highest score was 97, while the lowest score was 60 . It can be seen in chart 4. The average score from 18 students was 78.2. This means that most students have good at speaking.

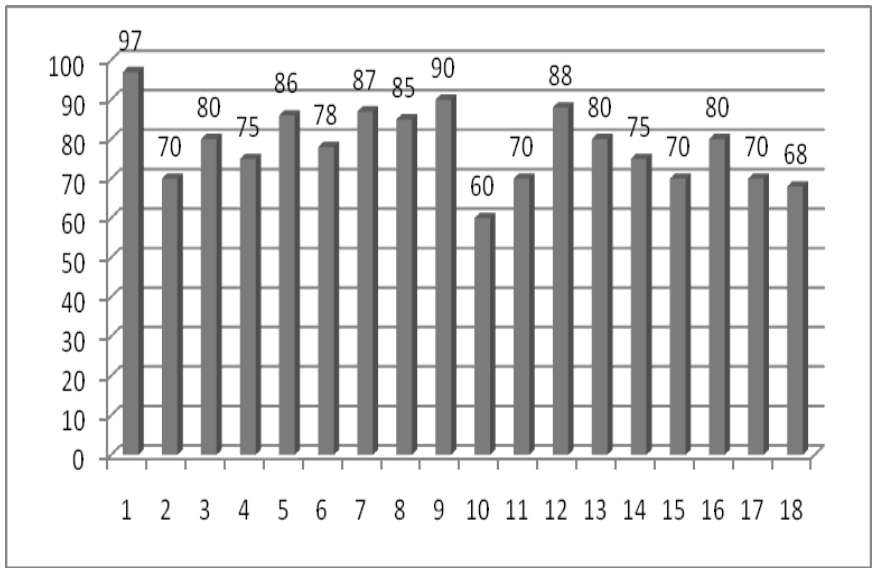

Chart 4. Speaking Score 
To strengthen the value of this study, here are some interpretations based on the results of data analysis. Based on the results of the study, it was found that 6 students were in a low level of speaking anxiety that uses ICT or daring learning and only 1 student had a high level in speaking anxiety while the students who used direct method or face to face learning, 3 students were in a high level of speaking anxiety. It can be assumed that using an application like zoom meeting will lead the students more confidence to speak up.

Based on the the scoring of speaking test, the result showed that most of the students got upper 60 which the highest was 97 with the average score was 78.2. The use of e-learning like zoom meeting lets them more confidence as their factor that can good score while other factors can not be explained.

The result of the study also obtained the scoring of students' speaking that all of the students got upper
60 and the highest score from 18 students was 97. The participation of students in zoom or google meetings can be assumed that ICT usage can help the students more active because they can find many sources to develop their knowledge easily and make them more confident.

\section{CONCLUSION}

In this study, the researcher aimed to determine the description of The Anxiety of English Speaking in ICT Usage as Media TEFL on Nursing Students of STIK Bina Husada Palembang. In this study, the researcher collected the data of anxiety of speaking ability by distributed the questionnaire and speaking test. From the data obtained, the percentage of students who showed the level of anxiety of speaking ability was more in low level who used online learning rather than use face to face learning. The use of ICT in the online learning process was very useful, it can lead the students to be brave to 
speak by using online learning as media

teaching and learning process, the

confidence of them can be seen from the

result.

\section{REFERENCES}

Brown, D. (2008). Teaching by principles. ( $2^{\text {nd }}$ Ed.). New York: LongmanUniversity Press.

Harmer, J. (2001). How to teach English. England: Pearson Education limited

Hennessy, S., Ruthven, K. \& Brindley, S. (2005). Teacher perspectives on integrating ICT into subject teaching: Commitment, constraints, caution and change. Retrieved from:

http://www.educ.cam.ac.uk/researc $\mathrm{h} /$ projects/istl/WP042.pdf

Livingstone, S. (2012). Critical reflections on the benefits of ICT in education, Oxford review of education. Retrieved from: http://dx.doi.org/10.1080/03054985 .2011 .577938

Luo, H. (2013b). Foreign Language Anxiety: Past and Future. Chinese Journal of Applied Linguistics, 36 (4), 442-464

Nunan, D. (2004). Research methods in language teaching. Cambridge: Cambridge University Press

Tarigan, H. G. (1990). Prinsip-prinsip dasar metode riset pengajaran dan pembelajaran bahasa. Bandung: Angkasa

Woodrow, L. (2006). Anxiety and Speaking English as a Second Language. RELC Journal, 37, 308328.

http://dx.doi.org/10.1177/00336882 06071315

Young. (1991). Language anxiety: From theory and research to classroom implications. Englewood : Prentice-Hall. 